\title{
Erratum to: 'Deregulation of the FOXM1 target gene network and its coregulatory partners in oesophageal adenocarcinoma'
}

\author{
Elizabeth F. Wiseman ${ }^{1,2}$, Xi Chen ${ }^{1,3}$, Namshik Han ${ }^{1,4}$, Aaron Webber ${ }^{1}$, Zongling Ji ${ }^{1}$, Andrew D. Sharrocks ${ }^{\text {* }}$ \\ and Yeng S. Ang ${ }^{2}$
}

After publication of this study [1], we discovered that we had unintentionally omitted to include an accession number for our ChIP-seq data. The ChIP-seq data for FOXM1 in OE33 cells is available at ArrayExpress; accession number E-MTAB-4121. In addition, we omitted to include lists of the high confidence and high coverage FOXM1 binding regions. This has now been amended in a revised Additional file 1: Table S1 which also now features a "legend" tab which more clearly explains the contents of each spreadsheet.

\section{Additional file}

Additional file 1: Table S1. FOXM1 binding regions identified using ChIPseq in OE33 and U2OS cell lines. Data are shown according to classification as high confidence (found in both replicates) or high coverage (found when reads are combined from both replicates and binding regions recalled). (XLSX $519 \mathrm{~kb})$

\section{Competing interests}

The authors declare that they have no competing interests.

\section{Authors' contributions}

EFW contributed to the study design, conducted the majority of the experiments, and helped with manuscript preparation. XC and ZJ also conducted experiments. XC, NH and AW performed the bioinformatics analysis. YSA provided clinical training, contributed to study design and coordination and data interpretation. ADS contributed to experimental design and coordination and wrote the manuscript. All authors read and approved the final manuscript.

\section{Author details}

${ }^{1}$ Faculty of Life Sciences, University of Manchester, Michael Smith Building, Oxford Road, Manchester M13 9PT, UK. ${ }^{2}$ Faculty of Medical and Human Sciences, University of Manchester, Oxford Road, Manchester, UK. ${ }^{3}$ Present address: The EMBL-European Bioinformatics Institute, Wellcome Trust Genome Campus, Hinxton, Cambridge CB10 1SD, UK. ${ }^{4}$ Present address: Gurdon Institute and Department of Pathology, Tennis Court Road, Cambridge CB2 1QN, UK.

\footnotetext{
* Correspondence: a.d.sharrocks@manchester.ac.uk

${ }^{1}$ Faculty of Life Sciences, University of Manchester, Michael Smith Building, Oxford Road, Manchester M13 9PT, UK
}

Received: 26 February 2016 Accepted: 26 February 2016 Published: 2 March 2016

\section{Reference}

1. Wiseman EF, Chen X, Han N, Webber A, Ji Z, Sharrocks AD, Ang YS. Deregulation of the FOXM1 target gene network and its coregulatory partners in oesophageal adenocarcinoma. Mol Cancer. 2015;14:69.
Submit your next manuscript to BioMed Central and we will help you at every step:

- We accept pre-submission inquiries

- Our selector tool helps you to find the most relevant journal

- We provide round the clock customer support

- Convenient online submission

- Thorough peer review

- Inclusion in PubMed and all major indexing services

- Maximum visibility for your research

Submit your manuscript at www.biomedcentral.com/submit

(n) 